\title{
A Research on the Influences of Transnational Merger and Acquisition on China's Industry Security
}

\author{
Jianhong Huang \\ Tourism College, Hainan University \\ Haikou 570228, China \\ Tel: 86-898-6625-0179 E-mail: yanhuang3721@yahoo.com.cn
}

\begin{abstract}
With the rapid development of China's economy, foreign investment in China's industry has got strengthened in both breadth and depth. Transnational corporations, one of the sources of foreign investment, have done frequent M\&A, hence having some actual and potential influences on China's industry or even economy security. This article begins with the current situation and characteristics of transnational corporations' M\&A, then moves on to the positive and negative influences transnational corporations' M\&A in the recent time have on China's industry security and puts forward some relevant strategies and suggestions for China about how to cope with M\&A from the aspect of making reasonable use of foreign capital.
\end{abstract}

Keywords: Transnational corporation, M\&A, Industry security, Influence

In the recent years, large-scale transnational M\&A has drawn much attention from a large number of scholars to China's industry security. Seen from the existing documents, the present theoretical researches on industry security in China are mainly focused on defining this term (Fu, 2007; He, 2006) and the policies of maintaining industry security ( $\mathrm{Li}, 2006$; Zhao, 2007). In addition, some experts attach their attention to analyzing the factors influencing industry security (Liu, 2005; Xu, 2004), conducting quantitative analyses and researches on china's industry security by constructing an index system to assess it $(\mathrm{He}, 2002)$. Generally speaking, however, China still lies in the fundamental stage in terms of the research on industry security, and therefore, some relevant theories are being discussed, constructed and formed. (He, 2006). Besides, the present analyses are mainly focused on the negative influences, hence neglecting the positive ones. Based on the current situation in China, this article explores the influences M\&A has on China's industry security objectively and comes to some strategies and suggestions to cope with the current situation from the perspective of how to make reasonable use of foreign investment.

\section{Current Situation of Transnational M\&A in China}

With the rapid development of China's economy, the constant optimization of industrial structure and the appearance of some new consumption demands such as automobiles, telecommunication, travelling, housing and so on, China has become a highlight at the global M\&A market. In the recent years, the M\&A by foreign capital has stepped into a brand-new development platform and has displayed the following characteristics: one after another record of the transaction scale of M\&A by foreign capital has been created; M\&A mainly happens in banking, manufacturing and Internet industries; the M\&A pattern has been renewed over and again; overseas buy-out funds have opened China's door. (Jing, 2005)

\subsection{Constantly Expanded M\&A Scale}

Recently, quite a few M\&A transactions involving a large sum of money have taken place in China's market, setting one record after another in both the sum of money and the number of transactions. For instance, in June 2005, U.S. Bank first invested \$ 2.5 billion in buying 9\% of China Construction Bank's shares held by China Huijin Investment Corporation Ltd. and then subscribed for \$ 0.5 billion's shares at CCB's overseas IPO. This has got the largest sum of single investment of foreign corporations in China's inland banks so far and has broken the record of $\$ 1.747$ billion set by Hong Kong and Shanghai Banking Corporation when buying the shares of Communications Bank of China. In addition, Yahoo also set the largest sum on Internet when buying Alibaba.com. China has become a focus attracting various kinds of industrial capital and financial capital all around the world. 


\subsection{Focusing on Banking Industry}

In terms of industry, M\&A mainly takes place in the industries related to banking, manufacturing and Internet, in which banking industry has become a focus. For example, Temasek invested $\$ 3$ billion in the shares of Bank of China; Pangaea Capital Manage bought $6.88 \%$ of Huaxia Bank's shares with 1 billion yuan; ING Group in Holland invested $€$ 0.196 billion in $19.9 \%$ of Beijing Bank's shares. In addition, most of M\&A transactions are conducted in the leading enterprises of different industries.

\subsection{Constantly Renewed M\&A Patterns}

There are mainly four M\&A patterns including rescue M\&A, cooperative M\&A, scrambling M\&A and hostile M\&A. With all the four patterns existing in China now, we should welcome the former two patterns while be on alert for the latter two.

\subsection{Investment of Foreign Funds}

China has become a hot spot for buy-out funds (Jing, 2005). In May 2004, Shenzhen Development Bank announced that they had sold $17.89 \%$ of its shares to foreign funds at the price of 1.253 billion yuan. In July 2005, Harbin Pharmaceutical Group was changed into a corporation Ltd controlled by the state from a former state-owned one. $34.76 \%$ of its shares flew from the state to the legal person. This is the first merger transaction in which a Chinese large-scale state-owned enterprise was bought by global buy-out funds. In addition, Carlyle Funds bought Xuzhou Construction Machinery Group in October 2006.

\section{The Influences of Transnational M\&A on China's Industry Security}

According to the definition of industry security (Fu, 2007; He, 2006; Zhao, 2007), the following standards can be employed to assess whether transnational M\&A influences industry security: whether closely related to national security; whether closely related to the fundamental needs in people's life; the technological level of certain industry; correlation degree among different industries ( impacts on other industries and influences on employment as well as economic growth; ecological environment factors (such as paper-making industry which is not quite significant in national economy but plays an important role in ecological environment); whether characterized as natural monopoly industry, whether an important strategic resource and so on.

\subsection{Positive Influences}

\subsubsection{Improving Employees' Quality}

Foreign corporations usually emphasize employees' quality training, hence contributing to the improvement of Chinese employees' quality. Foreign investment will provides better wages, treatment, working conditions as well as social welfare compared with that of Chinese enterprises to attract more excellent employees to their corporations. In addition, many transnational enterprises have set training bases in China to give their employees necessary training and further education, improving their overall quality to a large degree.

\subsubsection{Increasing Industrial Capital}

As one of the important channels of direct foreign investment, transnational M\&A plays an active part in the increase of China's industrial capital. According to the statistics provided by the Ministry of Commerce, there has been a stable growth in the number of newly-established projects (enterprises), the sum of contracted foreign investment and the actually-utilized sum in the eastern, middle and western parts of China since 2000. In 2005, 44001 foreign-invested enterprises were approved to be newly built, involving \$ 189.06454 billion worth of contracted foreign capital and $\$ 60.32469$ billion worth of actually-utilized sum, providing a solid foundation for China's economic development.

\section{Insert Table 1 here}

\subsubsection{Improving Overall Industrial Management Level}

After many years' operation, foreign enterprises have formed an orderly management system. Therefore, when an enterprise is merged by a foreign enterprise with high management level, its old system will give way to a new one, hence having its management efficiency improved. With great efforts, the management of both the merged enterprise but the merging one will be improved a lot.

\subsubsection{Optimizing Industrial structure}

Transnational M\&A is of significance in facilitating the paces of state-owned enterprises' reform and recombination, promoting the adjustment of national economy strategies, improving China's industrial structure and regulating and developing China's capital market ( Wang, 2006). In the past, due to China's planned economy, many units formed their fully-equipped but isolated system, resulting in a large amount of over-duplicated projects as well as the destruction of reasonable economic system and coordination. In addition, because of the small and dispersed scale, their centralization was not advanced enough. For instance, in 2003, China ranked first in beer output in the world with the record of 25.4 
million tons while only 3 beer manufacturers had an annual output of over 1 million tons. M\&A can help to promote the centralization of production and capital, strengthen enterprises' competitiveness at market, form a complementing and coordinating relationship among large, middle and small enterprises as well as a reasonable labor-division pattern.

Objectively speaking, on one hand, the entry of transnational corporations will do a lot to improve an industry's overall capacity. On the other hand, it will also have great impacts on Chinese enterprises.

\subsection{Negative Influences}

\subsubsection{Endangering National Security and People's Livelihood}

Some industries involved in transnational M\&A are related to national security or the fundamental needs in people's life. In October 2006, Carlyle Funds bought 50\% of the shares of Xuzhou Construction Machinery Group at the price of 1.8 billion yuan. Taking the previous large number of machinery enterprises bought by foreign capital into consideration, we can draw the conclusion that the control of foreign capital in machinery industry has gone to a dangerous edge because the production of many militarily machinery parts will be dominated by it. In the recent years, foreign capital has frequently merged China's manufacturing industry, banking industry, circulation industry as well as high-tech industry. Once these industries closely related to national economy and people's livelihood are controlled by foreign investment, China's base of independence in economy as well as politics will be destroyed totally.

\subsubsection{The Loss of Intellectual Property Rights}

If Chinese enterprises are merged by foreign capital, we will lose not only our national brands which were established with great efforts but our capacity in independent research and development. A nation's well-known brands are the soul of its national enterprises as well as the foundation of its industrial development. By M\&A, foreign capital has succeeded in weakening the foundation of China's industrial development as well as getting rid of its competitors. Of course, this will influence China's industrial development and security. As is well known, technology is not only the result of industry but the core power determining the development of industrial competitiveness. After M\&A, foreign capital will gain the core technologies of the merged enterprises as well as restrict their R\&D activities.

\subsubsection{Influencing Industrial Control}

When investing in China, transnational corporations usually adopt a pattern of "joint venture--pushing out Chinese enterprises-- foreign-owned--oligarchy monopoly". Although at the beginning of joint ventures and M\&A negotiations, Chinese enterprises have dominant shares, transnational corporations will take advantage of their strengths in capital, technology and management to increase their investment and expand their shares and finally ask for the ownership of the whole enterprise. After absorbing the leading enterprise in a certain industry, transnational corporations will employ the strategy of "the big fish eats fingerling" to merge or acquire other middle or small-scaled enterprises of this industry, hence controlling China's market and monopolize the whole industry. As a result, China's industry security will be endangered.

\subsubsection{Strengthening the Imbalance of Regional Economy}

The regional imbalance of China' economic development influences the distribution of target Chinese enterprises for transnational M\&A, and then, the obvious disparity in spatial distribution of transnational M\&A also influences the development of China's regional economy. Let's take GDP for example, the disparity in GDP of East China, Middle China and West China is getting wider. Compared with East China, the GDP total of Middle and West China was respectively $59 \%$ and $40 \%$ of that of East China in 1980 while dropped to $31 \%$ and $27 \%$ in 2004 . This shows the increasingly wider disparity among the three areas in China.

\section{Insert Table 2 here}

\section{Current Measures in Replying to Transnational M\&A in China}

Transnational M\&A has certainly had influences on China in many ways. However, it is totally wrong to be terrified of M\&A and put the clock back to the isolation age. The tide of global M\&A has brought about both challenges and opportunities. Therefore, Chinese enterprises are expected to face up to, study carefully and then solve difficulties. Only with the right methods and measures can we change difficulties into motivation, challenges into opportunities.

\subsection{Establishing Right Security Concept}

Now, with the weakening of national industry concept, the idea of national industrial security is changing. As is shown in practice, one may not control an enterprise by controlling its shares. Therefore, it is impractical for most Chinese enterprises to pursue the control of shares when negotiating with transnational corporations. However, it doesn't mean giving up other controls to give up the control of shares. No matter in developed countries or developing countries, it has been an effective method for the government to control those large-scale transnational corporations by issuing regulations. So a government regulation control system is in bad need in China, in which the idea emphasizing the general international practice should be established. It has been shown in many countries' opening practice that all of 
them will be safer only by interacting with each other in all industries. In future, in addition to the introduction of foreign capital and technology, the portion of export should be increased, hence maintaining a proper ratio between the two.

\subsection{Guiding he Direction of $M \& A$}

Due to the profit-oriented purpose of transnational M\&A in China, their investment will be in conflict with the development strategy of Chinese economy. Chinese government should encourage transnational corporations to extend to Middle and West China from East in order to promote the balanced development of China's regional economy; government should also guide the M\&A pattern to encourage rescue and cooperative M\&A instead of hostile one such as that happened to Wahaha; government should put restrictions on the range of M\&A, in which some industries closely related to national economy and people's livelihood, such as oil industry, manufacturing industry, banking industry, should be restricted in foreign investment while those high-exhaustion, high-pollution, poor-technology industries should welcome foreign investment. A reasonable guidance of M\&A will promote China to develop towards industrial advance.

\subsection{Improving Independent Innovation Capacity}

For a long term, although China has introduced a large amount of advanced technologies and facilities from foreign countries, many enterprises still fall into a situation of "introduction-lagging-repeated introduction-repeated lagging" due to their failure in absorbing what they have introduced. It is shown in Haier and Huawei's success stories that independent innovation is the source and motivation for an enterprise to exist and develop. Therefore, national enterprises should put much importance on staff training, improving their independent $R \& D$ capacity and promoting their own brands. In addition, government should issue some policies and measures to encourage independent innovation in order to increase enterprises' input in technological research and development.

\subsection{Establishing M\&A Examination and Approval Institution and System}

Measures for Strategic Investment by Foreign Investors upon Listed Companies, Stock Law and Regulations of Acquisition of a Listed Company have set a law framework for foreign capital's acquisition of listed companies. However, law itself is not enough. An institution in charge of the examination and approval of transnational M\&A should be established to have an overall examination of some potential influences caused by M\&A on employment, technological level, correlation degree among different industries, ecosystem, strategic resources and national security. In addition, a set of examination and approval systems should be established to have careful property definition and asset assessment in order to prevent state-owned asset from flowing out. Some state-regulated strategic industries, key enterprises, key products and key technologies should also be established to regulate foreign M\&A.

\subsection{Establishing Industry Security Early Warning System}

Such a system should be able to assess the security state of all industries firstly, to predict the future security tendency secondly and finally to deliver the information to government and enterprises. In addition, the security state of key industries should be paid special attention to in order to prevent transnational corporations from monopolizing the whole industry. Some industries involving insufficient or excessive competitions should be regulated in tome to keep a healthy, orderly and fair competition order.

\section{References}

Fu, Min. (2007). An Overview of Industry Security. Economic Theory and Business Management, (2).

He, Weida \& He, Chang. (2002). Rudimentary Assessment of Main Three Industries Safety Nowadays in China. China Industrial Economy, (2).

He, Weida \& Li, Dongmei. (2006). An Overview of Theoretical Research on China's Industry Security. Economic Review, (8).

Jing, Yuqin. (2005). A Research on China's Industry Security.

Li, Bingyan, \& Wang, Xiaogang. (2006). The Threat and Countermeasures of Massive Introduction Foreign Capital to Our Country Economic Security. (2).

Liu, Yong, Li, Qiaojing \& Sun, Xiao. (2005). On Multinational Direct Investment's Influence on China's Economy. Special Zone Economy, (5).

Wang, Wei. (2006). China's M\&A Report. Post \& Telecom Press.

Wang, Xinong. (2004). Enterprises and Government in Transnational M\&A. Chine Economy Publishing House.

$\mathrm{Xu}$, Bo. (2004). A Research on the $5^{\text {th }} M \& A$ Tide and Its Influence on China's Economy. China Commerce and Trade Press.

Zhao, Ying \& Li, Haijian et. al. (2007). An Overall Report of National Economy Security in the Open Environment. 
Table 1. Direct foreign investment in China by the end of 2005 (in 100 million US dollars)

\begin{tabular}{|c|c|c|c|}
\hline Year/Type & Number of projects & $\begin{array}{l}\text { Contracted foreign } \\
\text { capital }\end{array}$ & $\begin{array}{l}\text { Actually-utilized foreign } \\
\text { capital }\end{array}$ \\
\hline 2000 & 22347 & 623.80 & 407.15 \\
\hline 2001 & 26140 & 691.95 & 468.78 \\
\hline 2002 & 34171 & 827.68 & 527.43 \\
\hline 2003 & 41081 & 1150.70 & 535.05 \\
\hline 2004 & 43664 & 1534.79 & 606.30 \\
\hline 2005 & 44001 & 1890.65 & 603.24 \\
\hline
\end{tabular}

Data source: statistics of the Ministry of Commerce

Table 2. The utilization of direct foreign capital in Middle and West China by the end of 2005 (in 100 million US dollars)

\begin{tabular}{|l|l|l|l|l|l|l|}
\hline \multirow{2}{*}{ Name of areas } & \multicolumn{2}{|l|}{ Number of projects } & \multicolumn{2}{l|}{ Contracted foreign capital } & \multicolumn{2}{l|}{ Actually-utilized foreign capital } \\
\cline { 2 - 7 } & Number & $\begin{array}{l}\text { Percentage } \\
(\%)\end{array}$ & Sum & $\begin{array}{l}\text { Percentage } \\
(\%)\end{array}$ & Sum & Percentage (\%) \\
\hline Total & 552942 & 100 & 12856.7299 & 100 & 6224.2531 & 100 \\
\hline East China & 457944 & 82.82 & 11174.7601 & 86.92 & 5383.7139 & 86.5 \\
\hline Middle China & 59947 & 10.84 & 1003.0724 & 7.8 & 562.9589 & 9.04 \\
\hline West China & 35051 & 6.34 & 678.8974 & 5.28 & 277.5803 & 4.46 \\
\hline
\end{tabular}

Data source: statistics of the Ministry of Commerce 